慶應義塾大学学術情報リポジトリ

Keio Associated Repository of Academic resouces

\begin{tabular}{|c|c|}
\hline Title & Melatonin in serum and the pineal of spontaneously hypertensive rats \\
\hline \multicolumn{2}{|l|}{ Sub Title } \\
\hline Author & $\begin{array}{l}\text { 川島, 紘一郎(Kawashima, Koichiro) } \\
\text { 長倉, 明人( Nagakura, Akihito) } \\
\text { Wurzburger, Robert J. } \\
\text { Spector, Sydney }\end{array}$ \\
\hline Publisher & 共立薬科大学 \\
\hline Publication year & 1985 \\
\hline Jtitle & $\begin{array}{l}\text { 共立薬科大学研究年報 (The annual report of the Kyoritsu College of } \\
\text { Pharmacy). No.30 (1985. ), p.93- } 93\end{array}$ \\
\hline \multicolumn{2}{|r|}{ 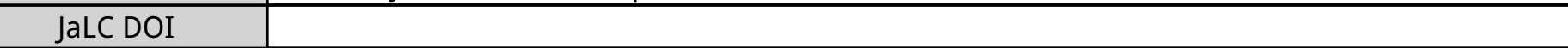 } \\
\hline \multicolumn{2}{|l|}{ Abstract } \\
\hline Notes & 抄録 \\
\hline Genre & Technical Report \\
\hline URL & $\begin{array}{l}\text { https://koara.lib.keio.ac.jp/xoonips/modules/xoonips/detail.php?koara_id=AN00062898-0000003 } \\
\text { 0-0093 }\end{array}$ \\
\hline
\end{tabular}

慶應義塾大学学術情報リポジトリ(KOARA)に掲載されているコンテンツの著作権は、それぞれの著作者、学会または出版社/発行者に帰属し、その権利は著作権法によって 保護されています。引用にあたっては、著作権法を遵守してご利用ください。

The copyrights of content available on the KeiO Associated Repository of Academic resources (KOARA) belong to the respective authors, academic societies, or publishers/issuers, and these rights are protected by the Japanese Copyright Act. When quoting the content, please follow the Japanese copyright act. 


\title{
Melatonin in Serum and the Pineal of Spontaneously Hypertensive Rats
}

\author{
Koichiro Kawashima, Akihito Nagakura*, \\ Robert J. WURZBURGER** and Sydney SPECTOR** \\ 川島紘一郎, 長倉明人*
}

Robert J. Wurzburger** and Sydney Spector**

\begin{abstract}
Involvement of melatonin in the blood pressure regulation as an endogenous central hypotensive factor has been suggested in rats and in man. We studied the relationship between melatonin and the development of hypertension in 5- and 15-week-old spontaneously hypertensive (SHR) and normotensive Wistar Kyoto (WKY) rats, by measuring serum and the pineal concentrations with a sensitive and specific radioimmunoassay coupled with a novel extraction method. Serum melatonin concentration at midnight in young SHR rats was significantly higher than that in age-matched WKY rats $(p<0.01)$, whereas it was decreased in the adult SHR $(p<0.01)$. No such differences were observed at noon. Pineal content of melatonin at midnight in 5-week-old SHR rats was lower than in age-matched WKY rats $(p<0.01)$. These data demonstrate that melatonin in the nocturnal serum of SHR rats is elevated at prehypertensive stage while it is decreased after the development of hypertension. The role of melatonin in the hypertensive process in SHR rats requires further study.
\end{abstract}

本報告は Clin. and Exper.-Theory and Practice, A 6 (8), 1517-1528（1984）江発表

* 日本ベーリンガーインゲルハイム

** Roche Institute of Molecular Biology 